\title{
IZSELJEVANJE IZ BENEŠKE SLOVENIJE V SEVERNO AMERIKO NA ZAČETKU 20. STOLETJA NA PODLAGI LADIJSKIH POTNIŠKIH SEZNAMOV
}

\author{
Aleksej KALC
}

COBISS 1.01

\section{IZVLEČEK \\ Izseljevanje iz Beneške Slovenije v Severno Ameriko na začetku 20. stoletja \\ na podlagi ladijskih potniških seznamov}

Avtor izseljevanje iz Beneške Slovenije v ZDA v prvih desetletjih 20. stoletja analizira na podlagi seznamov ladijskih potnikov, ki so jih $v$ vstopnih pristaniščih sestavljale ameriške oblasti. Razpravlja o dinamičnih in strukturnih vidikih ter pomenu preusmerjanja od kontinentalnih k atlantskim delovnim migracijam, ki so delno ohranjale začasno naravo in konzervativno ekonomsko vlogo, večinoma pa prehajale $v$ trajno naselitev izseljencev v Ameriki. Opozarja na prelomni značaj pojava, s katerim se je začelo stalno izseljevanje iz beneškoslovenskih dolin in prikazuje logistična in socialna stališča ter vlogo družbenih mrež, ki so delovale kot oporni sistem izseljevanja in ohranjanja čezoceanskih vezi.

KLJUČNE BESEDE: Beneška Slovenija, Furlanija, izseljevanje, Amerika, potniški seznami

\section{ABSTRACT \\ Emigration from Venetian Slovenia to North America at the Beginning of the $20^{\text {th }}$ Century on the Basis of Passenger Lists}

The paper discusses emigration from Venetian Slovenia to the USA in the early decades of the 20th century on the basis of passenger lists compiled by the US immigration authorities. It illustrates the dynamic and structural characteristics of the movements and the typological change from seasonal continental to transatlantic labour migration. The overseas migration was also intended to be temporary and was part of the conservative socio-economic strategies of the rural communities. However, in many cases it led to the permanent settling of the emigrants in the USA. This marked the beginning of permanent emigration from Venetian Slovenia and introduced the process of depopulation of the region. The logistical aspects and the role of social networks in the migration and settlement process are discussed as well.

KEY WORDS: Venetian Slovenia, Friuli, emigration, America, passenger lists

\footnotetext{
Dr. Aleksej Kalc, izr. prof., Znanstvenoraziskovalni center Slovenske akademije znanosti in umetnosti, Inštitut za slovensko izseljenstvo in migracije, Novi trg 2, SI-1000 Ljubljana; AKalc@ zrc-sazu.si - Prispevek je rezultat dela na projektih "Socialna, gospodarska in kulturna zgodovina slovenskega izseljenstva« (št. J5-7167) in »Nadzor nad migracijami na Slovenskem od Avstro-Ogrske do samostojne Slovenije« (št. J6-8250) ter raziskovalnem programu »Narodna in kulturna identiteta slovenskega izseljenstva v kontekstu raziskovanja migracij« (št. P5-0070). Oba projekta in raziskovalni program Javna agencija za raziskovalno dejavnost Republike Slovenije sofinancira iz državnega proračuna.
} 


\section{BENEŠKA SLOVENIJA V FURLANSKEM KONTEKSTU}

V desetletjih pred prvo svetovno vojno so prebivalci Beneške Slovenije od pomladi do jeseni množično odhajali na sezonsko delo. Tovrstna delovna migracija je bila značilna za celotno Furlanijo, od koder se je iz leta v leto odpravljalo na pot v Avstrijo, na Ogrsko in v Nemčijo do 50.000 migrantov (Cosattini 1903: 16-24). Zaposlovali so se kot poklicni in navadni delavci v gradbeništvu, pri gradnji in vzdrževanju prometnih in drugih infrastrukturnih objektov, stanovanjskih hiš, v opekarnah in kmetijstvu. $\mathrm{Na}$ začetku 20. stoletja se je v Beneški Sloveniji nenadoma razmahnilo tudi izseljevanje $\checkmark$ Severno Ameriko. V primerjavi s sezonsko se je ta migracija izraziteje pojavila samo še v nekaj drugih okrajih Furlanije in je zato pritegnila posebno pozornost sočasnih opazovalcev selitvenih gibanj in družbenoekonomskih razmer. Nanjo je leta 1909 opozorila anketa furlanskega inšpektorata za delo (Picotti 1909), kot posebnost Beneške Slovenije jo je geograf Francesco Musoni obravnaval v svojem znamenitem vodiču po Julijskih Predalpah (Musoni 1912: 133), medtem ko je duhovnik Luigi Ridolfi v knjigi o Furlanih v Severni Ameriki omenil beneškoslovenske kolonije v Clevelandu, Detroitu, Čikagu in drugod po ZDA ter v Kanadi (Ridolfi 1921). To pa je tudi vse, kar je bilo takrat napisanega o tem pojavu, ki je prav poldrugo desetletje pred prvo svetovno vojno v Vzhodni in Jugovzhodni Evropi dosegel svoj vrhunec. Tudi po drugi svetovni vojni, ko so selitvena gibanja postala osrednja tema preučevanja zgodovinskih in aktualnih vprašanj Beneške Slovenije, je bil pojav čezoceanskega izseljevanja pred prvo svetovno vojno deležen v glavnem le omemb (Kalc, Kodrič 1992). Z minevanjem generacij in $s$ pretrganjem sorodstvenih vezi je tako zgodovinski spomin na čezoceanski tok in beneškoslovensko prisotnost v Severni Ameriki skoraj popolnoma zbledel.

Namen pričujočega prispevka je zapolniti omenjeno vrzel in osvetliti potek, strukturne značilnosti in nekatera druga stališča množičnega izseljevanja iz Beneške Slovenije v Severno Ameriko v dobi t. i. »velikega izseljevanja«. Prikaz temelji na podatkih s 'seznamov ladijskih potnikov' (Passenger Lists), ki jih je v vstopnih pristaniččih sestavljala uprava za priseljevanje $v$ ZDA. Tu so prišleke registrirali in preverili njihovo zdravstveno stanje ter druge pogoje, preden so jih pustili $v$ državo ali pa jih zavrnili in poslali v njihove domovine. Sezname ladijskih potnikov so kot zgodovinski vir za preučevanje čezoceanskih migracij uporabile že mnoge študije. Nekatere, nanašajoče se na Avstro-Ogrsko, so primerjalno $z$ drugimi etničnimi skupinami zajele tudi izseljence s slovenskega ozemlja (Steidl 2009, 2014). Pričujoča razprava se prvič posveča samo slovenskim priseljencem. $V$ nasprotju z drugimi, ki obravnavajo skupine ladijskih potnikov iz posameznih let, obravnava priseljevanje in priseljence z ožjega geografskega območja, in to tudi v diahroni perspektivi. S tem ponuja vpogled $v$ nekatere značilnosti čezoceanskega izseljevanja v obravnavanem časovnem loku na Slovenskem, ki še niso bila deležna podrobnejših empiričnih preučevanj, in prispeva k razpravi o obravnavani problematiki. 


\section{„PASSENGER LISTS« KOT VIR ZA ZGODOVINO ČEZOCEANSKIH MIGRACIJ}

Seznami ladijskih potnikov so največji korpus individualnih podatkov o priseljevanju v ZDA. Uvedli so jih leta 1819 z Zakonom o regulaciji pomorskega prevoza in jih nato prilagajali potrebam identifikacije, nadzorovanja in selekcije priseljencev $v$ skladu s priseljensko in z varnostno politiko. Do devetdesetih let 19. stoletja so jih vodili v okviru carinske službe, od leta 1892 pa organi za priseljevanje in naturalizacijo. V svoji končni obliki, od leta 1907, seznami (s polnim imenom List or Manifest of Alien Passengers for the United States Immigration Officer at Port of Arrival) obsegajo 29 rubrik in še nekatere podatke. $\mathrm{Na}$ enem samem mestu torej prinašajo izredno število informacij tako o vsakem posamezniku kot tudi podrobno skupinsko sliko migrantov. Poleg imena pristanišča, imena ladje in ladjarske družbe, datuma odhoda iz Evrope in prihoda v Ameriko vsebujejo ime in priimek priseljencev, starost, stan, poklic, stopnjo izobrazbe, državljanstvo, rasno pripadnost, telesne karakteristike, podatke o zdravstvenem stanju, moralne in politične oznake, državo in kraj rojstva ter državo in kraj, v katerega je bil priseljenec namenjen. Nadalje vsebujejo državo in kraj zadnjega bivališča, kraj, čas in trajanje prejšnjih bivanj v ZDA, ime, priimek, sorodstveno razmerje in naslov priseljenčevega sorodnika v izvornem kraju, priimek in naslov kontaktne osebe $v$ Ameriki, nazadnje pa še vsoto denarja, ki jo je prišlek prinašal s seboj (Kalc 1996: 52-55). Na voljo so torej tudi podatki, iz katerih je mogoče sklepati o oblikah in načinih izseljevanja, ter informacije o zvezah med ljudmi v starem kraju in novem svetu. Sosledje oseb v seznamih, njihov krajevni izvor in sorodstvena razmerja govorijo o načinih potovanja in fazah priseljevanja. Ladijski seznami potnikov dopuščajo več analitičnih pristopov in kvantitativno preučevanje tematskih vidikov, ki so drugače predmet mikroraziskav o individualnih primerih na podlagi kvalitativnih virov.

Raba tega serijskega vira, ki ga hranijo v nacionalnem arhivu v Washingtonu in New Yorku, ni ne tehnično ne metodološko preprosta. Podatke je treba izpisati, še prej pa je treba izbrati sezname, ki ustrezajo ciljem raziskave, glede na to, da je ob takem obsegu gradiva nujen vzorčni pristop. $V$ osemdesetih letih prejšnjega stoletja so nastale prve elektronske podatkovne baze s segmenti tega gradiva (Glazier 1984). Hkrati je stekla sistematična informatizacija seznamov, ki sta jo spodbudila zanimanje »iskalcev družinskih korenin « in tržna vrednost vsebovanih podatkov. Informatizirani podatki in elektronske kopije izvirnih seznamov so danes na voljo na rodoslovnih spletnih straneh. Te so prilagojene za iskanje posameznih oseb na podlagi priimka in imena in ne dopuščajo izbora po kraju izvora ali drugih klasifikacijah. Nabor priseljencev iz Beneške Slovenije je bilo mogoče izvesti s pomočjo beneškoslovenskih priimkov, ki so lahko razpoznavni in tipični za to geografsko območje. $Z$ vnašanjem priimkov $v$ rodoslovni brskalnik Winfamily.com so bili evidentirani seznami, $v$ katerih se pojavljajo potniki iz Beneške Slovenije. Z njimi je bila ustvarjena baza s podatki o 2.170 prihodih $v$ ZDA od začetka stoletja do konca tridesetih let. Dejanskih priseljencev je bilo manj, ker jih je nekaj prišlo v Ameriko po večkrat. Podatkovna zbirka 
tudi ne vsebuje vseh prihodov iz Beneške Slovenije, ker manj razširjeni priimki niso bili upoštevani, nekaterih primerov pa iskalnik ne izvrže zaradi napačnega prepisa $v$ iskalni sistem rodoslovne elektronske baze. $\mathrm{V}$ analizo je bilo zajetih 2.031 prihodov, ker smo izločili državljane in priseljence $s$ stalnim bivališčem $v$ ZDA, ki so se vračali z obiskov v starem kraju. $V$ bazi podatkov je po naši presoji zastopanih kakih 80 odstotkov prihodov iz Beneške Slovenije, ki dovolj reprezentativno odražajo dinamične in strukturne značilnosti čezoceanskega migracijskega pojava. Razen če ni posebej navedeno, se izrazi Beneški Slovenci, prekooceanski priseljenci oziroma izseljenci iz Beneške Slovenije nanašajo na primere, zabeležene v opisani podatkovni bazi.

\section{IZ BENEČIJE V AMERIKO}

Izseljevanje iz Benečije v Severno Ameriko se je pojavilo in nenadno razbohotilo med začetkom stoletja in prvo svetovno vojno (Grafikon 1). $V$ tem obdobju je bilo na Ellis Islandu v New Yorku registriranih 80 odstotkov vseh primerov iz podatkovne baze. To so bila leta največjega priseljevanja iz Vzhodne in Jugovzhodne Evrope $v$ Severno Ameriko, pri čemer so po obsegu izseljenskih kontingentov prednjačile Avstro-Ogrska, Rusija in Italija. V Ameriki so temu priseljevanju, da so ga razlikovali od 'stare migracije' (old immigration), ki je prihajala iz zahodnih in severnih evropskih držav, rekli 'nova migracija' (new immigration) Nova imigracija je začela naraščati v sedemdesetih letih in je v osemdesetih številčno že presegla staro.

Grafikon 1: Število priseljencev iz Beneške Slovenije v ZDA 1901-1940

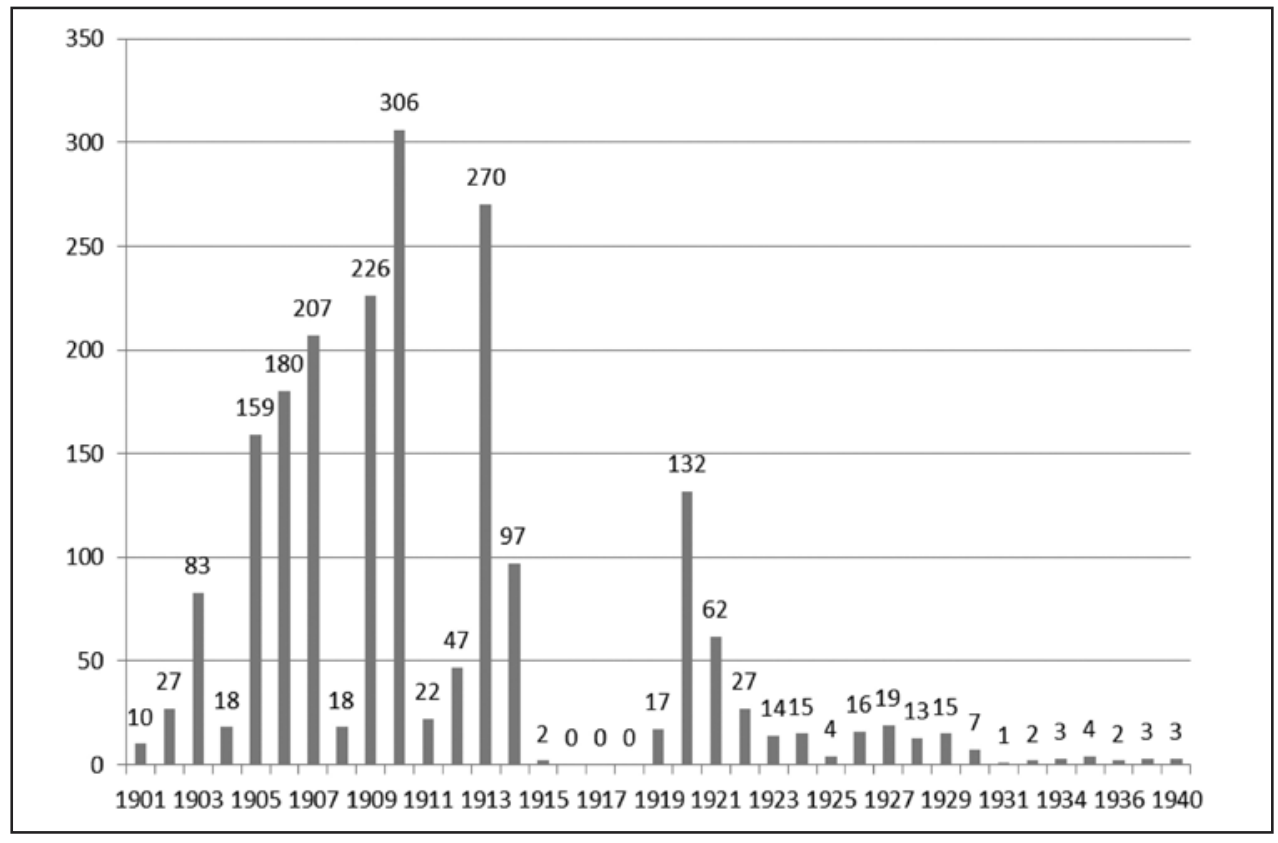


Tabela 1: Priseljenci iz Beneške Slovenije v ZDA po spolu in število vnovič priseljenih 1901-1940

\begin{tabular}{|c|c|c|c|c|c|c|c|c|}
\hline \multirow[b]{2}{*}{ Leto } & \multicolumn{4}{|c|}{ Število } & \multicolumn{4}{|c|}{ Odstotki } \\
\hline & Moški & Ženske & Skupno & $\begin{array}{c}\text { Vnovič } \\
\text { priseljeni }\end{array}$ & Moški & Ženske & Skupno & $\begin{array}{c}\text { Vnovič } \\
\text { priseljeni }\end{array}$ \\
\hline 1901 & 10 & & 10 & & 0,6 & 0,0 & 0,5 & \\
\hline 1902 & 23 & 4 & 27 & & 1,3 & 1,4 & 1,3 & \\
\hline 1903 & 81 & 2 & 83 & & 4,6 & 0,7 & 4,1 & \\
\hline 1904 & 18 & & 18 & & 1,0 & 0,0 & 0,9 & \\
\hline 1905 & 156 & 3 & 159 & 9 & 9,0 & 1,0 & 7,8 & 5,7 \\
\hline 1906 & 171 & 9 & 180 & 6 & 9,8 & 3,1 & 8,9 & 3,3 \\
\hline 1907 & 197 & 10 & 207 & 5 & 11,3 & 3,5 & 10,2 & 2,4 \\
\hline 1908 & 9 & 9 & 18 & 5 & 0,5 & 3,1 & 0,9 & 27,8 \\
\hline 1909 & 215 & 11 & 226 & 67 & 12,3 & 3,8 & 11,1 & 29,6 \\
\hline 1910 & 290 & 16 & 306 & 57 & 16,6 & 5,5 & 15,1 & 18,6 \\
\hline 1911 & 19 & 3 & 22 & 5 & 1,1 & 1,0 & 1,1 & 22,7 \\
\hline 1912 & 35 & 12 & 47 & 9 & 2,0 & 4,2 & 2,3 & 19,1 \\
\hline 1913 & 251 & 19 & 270 & 71 & 14,4 & 6,6 & 13,3 & 26,3 \\
\hline 1914 & 78 & 19 & 97 & 19 & 4,5 & 6,6 & 4,8 & 19,6 \\
\hline 1915 & & 2 & 2 & & 0,0 & 0,7 & 0,1 & \\
\hline \multicolumn{9}{|l|}{1916} \\
\hline \multicolumn{9}{|l|}{1917} \\
\hline \multicolumn{9}{|l|}{1918} \\
\hline 1919 & 8 & 9 & 17 & 5 & 0,5 & 3,1 & 0,8 & 29,4 \\
\hline 1920 & 89 & 43 & 132 & 12 & 5,1 & 14,9 & 6,5 & 9,1 \\
\hline 1921 & 37 & 25 & 62 & 6 & 2,1 & 8,7 & 3,1 & 9,7 \\
\hline 1922 & 11 & 16 & 27 & 4 & 0,6 & 5,5 & 1,3 & 14,8 \\
\hline 1923 & 10 & 4 & 14 & 2 & 0,6 & 1,4 & 0,7 & 14,3 \\
\hline 1924 & 5 & 10 & 15 & 3 & 0,3 & 3,5 & 0,7 & 20,0 \\
\hline 1925 & 1 & 3 & 4 & 1 & 0,1 & 1,0 & 0,2 & 25,0 \\
\hline 1926 & 6 & 10 & 16 & 4 & 0,3 & 3,5 & 0,8 & 25,0 \\
\hline 1927 & 8 & 11 & 19 & 3 & 0,5 & 3,8 & 0,9 & 15,8 \\
\hline 1928 & 3 & 10 & 13 & 2 & 0,2 & 3,5 & 0,6 & 15,4 \\
\hline 1929 & 2 & 13 & 15 & 1 & 0,1 & 4,5 & 0,7 & 6,7 \\
\hline 1930 & 4 & 3 & 7 & & 0,2 & 1,0 & 0,3 & \\
\hline 1931 & & 1 & 1 & & & 0,3 & 0,0 & \\
\hline 1932 & & 2 & 2 & 1 & 0,0 & 0,7 & 0,1 & 50,0 \\
\hline 1933 & & & & & 0,0 & 0,0 & 0,0 & \\
\hline 1934 & 2 & 1 & 3 & 2 & 0,1 & 0,3 & 0,1 & 66,7 \\
\hline 1935 & 1 & 3 & 4 & & 0,1 & 1,0 & 0,2 & \\
\hline 1936 & & 2 & 2 & 1 & 0,0 & 0,7 & 0,1 & 50,0 \\
\hline 1937 & 1 & 2 & 3 & & 0,1 & 0,7 & 0,1 & \\
\hline \multicolumn{9}{|l|}{1938} \\
\hline \multicolumn{9}{|l|}{1939} \\
\hline 1940 & 1 & 2 & 3 & & 0,1 & 0,7 & 0,1 & \\
\hline Skupno & 1742 & 289 & 2031 & 300 & 100 & 100 & 100 & \\
\hline
\end{tabular}


Časovni zamik, s katerim se je v Beneški Sloveniji čezoceansko izseljevanje začelo tudi v primerjavi s preostalim slovenskim izseljevanjem, ki se je $v$ množični obliki odvijalo že $v$ devetdesetih letih (Drnovšek 1999: 417), sovpada z regionalnimi tendencami italijanskega izseljevanja. Medtem ko je bilo z juga in iz srednjega dela polotoka to usmerjeno predvsem $v$ Severno Ameriko, je $v$ severnih italijanskih deželah čezoceanske tokove pritegnila predvsem Južna Amerika. V vseh deželah alpskega loka pa so prevladovale sezonske kontinentalne migracije. Šele ko je italijansko čezoceansko izseljevanje na začetku 20. stoletja doseglo višek, se je odhajanje $\checkmark$ Severno Ameriko močneje razširilo tudi na severu polotoka. To se je ujemalo $s$ ciklusi ekonomskega razvoja v Italiji in ZDA in s tipološko preobrazbo severnoameriškega trga dela ter načinov proizvodnje, ki je zaposlovala vse več nižje kvalificiranih in nekvalificiranih delavcev (Sori 1979: 19-65). Pomembna spodbuda sta bila tudi višja vrednost ameriških mezd in ugodno razmerje med zaslužkom in stroški čezoceanskega potovanja (Keeling 2012: 7). Tudi v Beneški Sloveniji je bila sezonska migracija že tradicionalno vgrajena $v$ gospodarski sistem in je $v$ zadnjih desetletjih 19. stoletja postajala vse pomembnejši vir družinskega dohodka (Kalc, Kodrič 1992). Preusmeritev v Severno Ameriko je pomenila preklop s tradicionalnega na alternativni, atlantski trg dela.

Prvih deset priseljencev iz nabora podatkov je pripotovalo v ZDA 19. oktobra 1901 in nadaljevalo pot v industrijsko mesto Indianapolis v zvezni državi Indiani. Niso bili prvi priseljenci iz Benečije, saj sta jih v tem mestu čakala dva sovaščana. Podobno so se na nekatere že priseljene rojake, ki jih prek rodoslovnega iskalnika ni bilo mogoče najti, sklicevali prišleki iz let 1902 in 1903, namenjeni v Čikago in Cleveland. Ti predhodni priseljenci, ki v ZDA najbrž niso prišli veliko prej, so odprli pot verižnemu procesu, ki se je sprožil leta 1903, ko se je število prihodov že potrojilo. Priseljenci iz leta 1902 so bili iz vasi Srednje in Sveti Lenart, iz leta 1903 pa že iz vseh občin v Nadiških dolinah in nekateri iz Terske doline. Usmerili so se tudi v Pensilvanijo, Minnesoto, Washington in New York, nekaj pa jih je šlo v kanadsko državo British Columbijo, točneje $v$ rudarsko mesto Nanaimo. $V$ tukajšnjih premogovnikih so nekateri delali že na začetku devetdesetih let 19. stoletja (Specogna 2009).

Izseljevanje je nihalo, saj so se ob prihodih v Ameriko vrstili tudi povratki v stari kraj. Priseljenskemu valu do leta 1903 je sledil mnogo večji med letoma 1905 in 1907, ko je iz Benečije prišlo 27 odstotkov vseh priseljencev. Nizko število prihodov leta 1908 je povezano s finančno in z gospodarsko krizo, zaradi katere je priseljevanje $v$ ZDA močno upadlo in se je zaradi pomanjkanja dela povečal povratni tok $v$ Evropo. S koncem krize je dotok ljudi iz Evrope znova narasel in v letih 1909 in 1910 je iz Beneške Slovenije dopotovalo v ZDA dobrih 26 odstotkov vseh evidentiranih priseljencev. Leta 1910 je pojav z več kot 300 prihodi dosegel višek. Spet je sledilo krizno obdobje, dokler ni leta 1913 priseljevanje ponovno oživelo in se približalo obsegu iz leta 1910. Nihanja priseljenskega procesa so bila odvisna od kriz in ponovnih izboljšanj ekonomskih razmer. Skoraj četrtina (23,3 odstotka) priseljenih iz Benečije v letih 1909 in 1910 je bila povratnikov, ki so se vrnili v domovino med krizo, točneje, 
58,2 odstotka leta 1908, 22,7 odstotka pa že leta 1907. Tudi med priseljenimi leta 1913 je bila več kot četrtina takih, ki so bili že prej v Ameriki, od katerih se je dobra polovica (54,9 odstotka) vrnila v letih 1911 in 1912.

Zaradi izbruha vojne je v drugi polovici leta 1914 izseljevanje upadlo, saj so vojskujoče države omejile svobodo gibanja in človeške vire podredile potrebam vojskovanja in vojne ekonomije. Zadnji priseljenci iz Benečije so prispeli v ZDA leta 1915, hkrati so se tega leta nekateri vrnili v Italijo. Sklepati smemo, da se je vrnilo malo vojaških obveznikov, saj je bil odziv italijanskih izseljencev iz čezoceanskih dežel na vojaško mobilizacijo v Italiji zelo skromen. Ne samo zato, ker jim ni bilo do vojskovanja. V Ameriki so ostajali zaradi ekonomskih potreb njihovih družin, zadrževale pa so jih tudi ugodne razmere v ameriški industriji in mezde, ki so naraščale s proizvodnjo za potrebe vojskujočih držav. Italija je bila v glavnem prizanesljiva do tovrstnega dezerterstva, da bi si izseljencev ne odtujila in s tem zmanjšala priliv njihovih denarnih pošiljk v domovino. Leta 1919 je vprašanje rešila z amnestijo, na katero so mnogi izseljenci čakali že od samega začetka in so se zato lahko nemoteno vrnili v Italijo (Salvetti 1987).

Po vojni so zaradi poslabšanja gospodarskih razmer iz Benečije spet začeli odhajati v ZDA (Pagani 1968, 394). Prvi so šli na pot povratniki, nato so jim sledili še drugi. Da bi lajšala brezposelnost, je italijanska država izseljevanje spodbujala in povratnikom nudila celo brezplačen prevoz v Ameriko (Salvetti 1987: 291-293). Že v naslednjih letih pa so ZDA začele restriktivno priseljensko politiko in s sistemom kvot močno omejile možnosti vstopa italijanskih državljanov. S tem je bilo konec tudi množičnega izseljevanja iz Beneške Slovenije. V Ameriko so odhajali le še posamezniki, ki so jih k sebi na podlagi pravice o združevanju družin poklicali že ustaljeni priseljenci. Izseljencem iz Beneške Slovenije so se v povojnih letih ponudile dobre priložnosti zaposlovanja v Evropi, zlasti v Franciji, Italiji in Nemčiji. Nekateri so odšli v Argentino in sredi tridesetih let tudi v italijanske afriške kolonije (Kalc 2000: 197-198). Z začetkom avtarkične ekonomske politike leta 1927, s katero si je prizadevala zmanjšati gospodarsko odvisnost od drugih držav, je Italija tudi sama omejila izseljevanje in ga podredila meddržavnim dogovorom o napotitvi delovne sile.

\section{SPOL, STAROST IN STAN}

Furlanske in z njimi beneškoslovenske sezonske migracije so imele izredno poudarjen moški značaj. Leta 1900 je bilo na primer med 43.000 sezonci iz Furlanije samo pet odstotkov žensk (Cosattini 1903: 134). Ta razkorak je bil povezan z delitvijo spolnih vlog v družinski ekonomiji, ki je temeljila na kombinaciji agrarnih virov in dohodkov od sezonskega dela. Med odsotnostjo moških so domača kmečka opravila $v$ veliki meri padla na ženska ramena. Sicer so se ženske ukvarjale še z drugimi dejavnostmi in mnoge so se odločile za druge oblike delovne migracije. Zlasti dekleta so pred poroko hodila služit k mestnim družinam, med njimi tudi beneškoslovenske 
»dikle«. Tudi v Severno Ameriko so se izseljevali pretežno moški, saj je bilo žensk v skupnem seštevku le 16 odstotkov, če upoštevamo tudi v drugo priseljene, pa 14 odstotkov. Starostna struktura se je nekoliko razlikovala od strukture sezonskih kontinentalnih migrantov. Sezonsko delo je bilo stalna sestavina družinskega dohodka, tako da so se moški podajali na pot, vse dokler so jim to dopuščala leta. Za ZDA pa so se odločale predvsem mlajše generacije, saj je bilo več kot 54 odstotkov priseljencev ob prvem prihodu v Ameriko starih od 20 do 30 let, dobrih 11 odstotkov pa od 15 do 20 let (Tabela 2). Večina priseljencev je bila samskih fantov, ki so najpogosteje šli na pot med 20. in 25. letom. Poročenih je bilo več tudi v višji starosti, ker so mnogi odhajali v Ameriko po večkrat (Tabela 3). Vnovič priseljeni so bili namreč v 70 odstotkih poročeni. Število samskih je bolj nihalo in izraziteje naraščalo v letih najmočnejšega izseljevanja.

Tabela 2: Priseljenci po spolu in starosti (v odstotkih)

\begin{tabular}{|c|c|c|c|c|}
\hline & \multicolumn{2}{|c|}{ Moški } & \multicolumn{2}{c|}{ Ženske } \\
\hline Starost & Vsi & Brez vnovič priseljenih & Vse & Brez vnovič priseljenih \\
\hline $0-04$ & 0,7 & 0,9 & 5,9 & 6,1 \\
\hline $05-09$ & 0,9 & 1,1 & 8,3 & 8,6 \\
\hline $10-14$ & 0,6 & 0,8 & 3,1 & 3,2 \\
\hline $15-19$ & 9,6 & 11,5 & 10,7 & 10,7 \\
\hline $20-24$ & 25,7 & 29,2 & 35,3 & 36,1 \\
\hline $25-29$ & 24,5 & 24,9 & 17,3 & 16,8 \\
\hline $30-34$ & 14,6 & 12,5 & 10,4 & 10,4 \\
\hline $34-39$ & 11,3 & 9,1 & 3,8 & 3,9 \\
\hline $40-44$ & 7,7 & 6,4 & 2,8 & 0,0 \\
\hline $45-49$ & 3,3 & 2,8 & 0,3 & 0,7 \\
\hline $50-54$ & 0,8 & 0,8 & 1,0 & 0,7 \\
\hline $55-60$ & 0,2 & 0,1 & 0,7 & 0,4 \\
\hline $60-64$ & 0,1 & 0,1 & 0,3 & 100,0 \\
\hline Skupno & 100,0 & 100,0 & 100,0 & $\mathbf{2 8 0}$ \\
\hline Število & $\mathbf{1 7 4 2}$ & $\mathbf{1 4 5 1}$ & & \\
\hline
\end{tabular}


Tabela 3: Priseljenci in priseljenke po stanu in starosti (v odstotkih, starost $>15$ let)

\begin{tabular}{|c|c|c|c|c|c|c|}
\hline Leta & Samski* $^{*}$ & Poročeni* & Samski & Poročeni & Samske & Poročene \\
\hline $15-19$ & 18,3 & 0,2 & 16,6 & 0,1 & 23,2 & 4,0 \\
\hline $20-24$ & 42,2 & 8,0 & 40,8 & 6,0 & 56,3 & 30,6 \\
\hline $25-29$ & 26,2 & 24,1 & 26,9 & 22,3 & 17,0 & 25,0 \\
\hline $30-34$ & 7,3 & 22,9 & 8,1 & 24,7 & 2,7 & 21,8 \\
\hline $34-39$ & 3,8 & 19,5 & 4,5 & 21,4 & & 8,9 \\
\hline $40-44$ & 1,3 & 16,1 & 1,8 & 16,5 & 0,9 & 5,6 \\
\hline $45-49$ & 0,8 & 6,8 & 1,1 & 6,5 & & 0,8 \\
\hline $50-54$ & 0,1 & 2,0 & 0,1 & 1,8 & & 2,4 \\
\hline $55-60$ & & 0,2 & & 0,4 & & 0,8 \\
\hline $60-64$ & & 0,2 & & 0,1 & & \\
\hline Skupno & 100,0 & 100,0 & 100,0 & 100,0 & 100,0 & 100,0 \\
\hline $\begin{array}{c}\text { Samski/ } \\
\text { poročeni }\end{array}$ & 64,3 & 35,7 & 58,5 & 41,5 & 47,5 & 52,5 \\
\hline
\end{tabular}

(* brez vnovič priseljenih)

Grafikon 2: Dinamika moškega in ženskega priseljevanja (v odstotkih, starost >15 let)

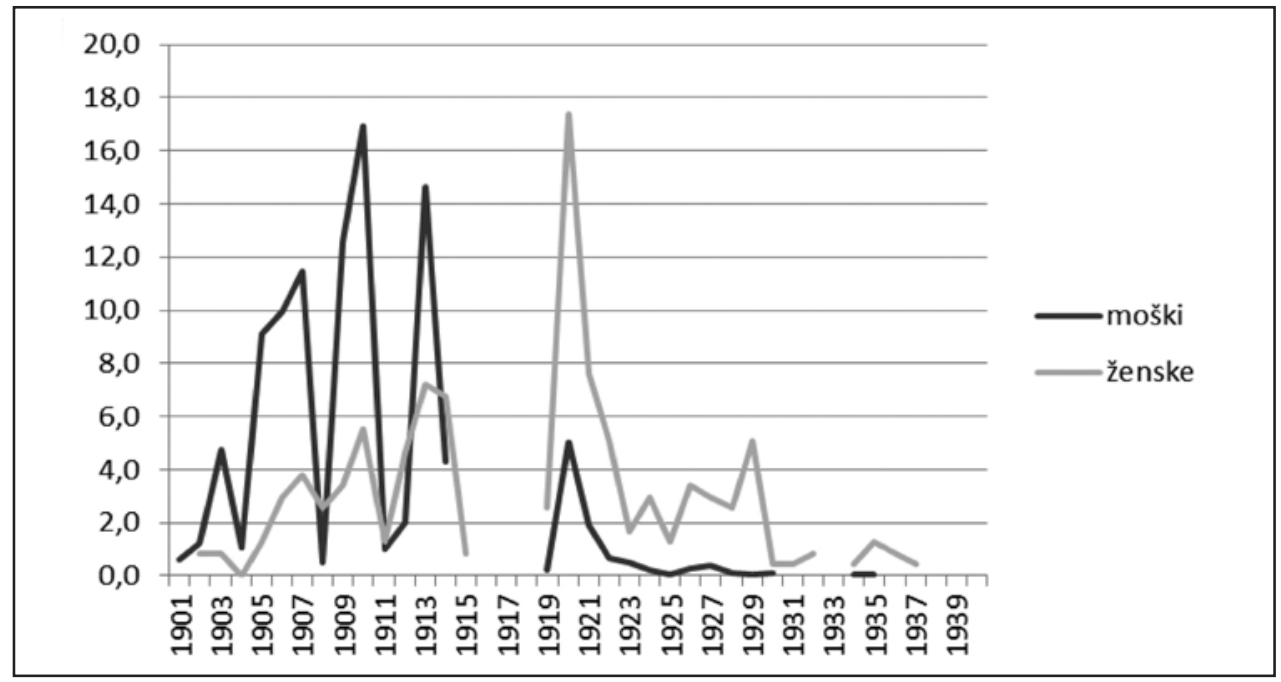

Žensko in moško priseljevanje sta sledila različnim dinamikam (Grafikon 2). Do vojne je iz Beneške Slovenije v Ameriko prišlo vsega samo 40 odstotkov priseljenk, medtem ko se je v istem obdobju zvrstilo skoraj 90 odstotkov vseh moških prihodov. Največ priseljenk je pripotovalo v začetku dvajsetih let. To je bilo povezano tako s težkimi gospodarskimi razmerami v Benečiji kot tudi s prelomnim zgodovinskim trenutkom, ko so se mnogi izseljenci odločili, da se ustalijo v ZDA in so k sebi poklicali družinske 
člane. Več kot polovica priseljenk je bila poročenih, in so pripotovale z otroki, od dojenčkov do najstnikov. Njihov dotok je bil v letih precej enakomeren. Samske ženske so se podobno kot moški pojavljale $v$ vrhuncih priseljenske dinamike, predvsem pa po vojni. Takrat jih je v treh letih prišla več kot polovica, samo leta 1920 dobrih 30 odstotkov. Priseljenke so se pridružile soprogom, zaročencem ali drugim članom družine in sorodstva, ki so se odločili za trajno ali daljše bivanje $v$ Ameriki. V vseh primerih je žensko doseljevanje odražalo stabilizacijski trenutek v priseljenskem procesu. $\mathrm{Na}$ to opozarjajo maloštevilni primeri povratnic med priseljenkami, ki jih je bilo samo devet ali tri odstotke. Narava ženskega priseljevanja in stabilizacijska vloga priseljenk v migracijskih načrtih družin ter v procesu oblikovanja priseljenskih skupnosti v Ameriki sta v ladijskih seznamih eksplicitno izpričani v rubriki, ki je spraševala, koliko časa se bo prišlek zadržal v ZDA. Velika večina priseljenk je izjavila, da prihaja za stalno.

Številčno nesorazmerje med spoloma in prevlada moških sta bila značilna bolj ali manj za vsa takratna transnacionalna migracijska gibanja (Donato, Gabaccia 2015). Spolni sestav čezoceanskih tokov se je razlikoval glede na tipologijo izseljevanja, razmere v izvorni in sprejemni deželi kot tudi po posameznih fazah selitvenega procesa. Med priseljenci iz Ogrske, na primer, je število žensk na prelomu stoletja hitro naraščalo in je pred prvo svetovno vojno celo presegalo število moških (Puskas 1991: 221). Med Čehi, avstrijskimi Nemci in avstrijskimi Judi je bilo leta 1910 žensk nad 40 odstotkov, med Ukrajinci in Poljaki nad 30 odstotkov (Steidl 2009: 215). Med izseljenci iz južnoslovanskih dežel je bil ženski delež najmanjši. Med slovenskimi in hrvaškimi priseljenci, ki jih je ameriška statistika vodila skupaj, je moška komponenta v prvih sedmih letih 20 . stoletja prevladovala s kar 86 odstotki, šele v naslednjem obdobju do prve vojne se je število priseljenk povečalo na 25 odstotkov (Willcox 1929). Annemarie Steidl povezuje to značilnost s pretežno začasno naravo izseljevanja in s tem, da so moški delali v rudarskih revirjih in središčih težke industrije, kjer za ženske ni bilo primernih priložnosti zaposlovanja in prijaznih življenjskih razmer (Steidl 2009: 216).

V primeru Benečije je treba spolne značilnosti ameriškega toka brati tudi z upoštevanjem strukturnega položaja migracij v gospodarskem sistemu tega območja. Sezonska migracija je $v$ kombinaciji $s$ tradicionalno agrarno ekonomijo kljub nezadostnim krajevnim gospodarskim virom družinam in vaškim skupnostim omogočala ohranitev v izvornih krajih. Tudi čezoceansko izseljevanje je imelo v številnih primerih podobno vlogo, in izseljenci so odhajali z namenom, da se po nekaj letih vrnejo. Sčasoma pa jih je vse več ostajalo v Ameriki. Na to odločitev sta vplivala tudi vojna in povojni kvotni sistem, ki je povratnikom skrajno omejil možnosti ponovnega vstopa v ZDA. Ker se je izseljevanje začelo šele na začetku stoletja, $v$ beneškoslovenskih priseljenskih vrstah v ZDA niso dozorele družbene razmere za večje število žensk, ki bi se jim pridružile. Po prvi svetovni vojni so se ženske migracije v Benečiji okrepile, pretežno pa so sledile samostojnim potem in se zaposlovale na trgu hišnega dela v italijanskih mestih. Tako je bilo ob ljudskem štetju leta 193180 odstotkov začasno odsotnih žensk iz občine Sovodnje v drugih italijanskih občinah, kjer so mnoge 
ostale in si ustvarile družine (Meneghel, Battigelli 1977: 141). Učinki prehajanja od sezonskega tipa $k$ trajnejšim oblikam izseljevanja so se po prvi vojni začeli odražati tudi v razvoju prebivalstva Beneške Slovenije, ki je po 50 letih neprestane rasti začelo številčno upadati (Clavora, Ruttar 1990: 60). To tendenco, značilno za celotno hribovito Furlanijo (Gortani, Pittoni 1938), je v Benečijo prineslo izseljevanje v Ameriko.

\section{IZVOR, CILJI IN POT V AMERIKO}

Beneškoslovensko izseljevanje v Severno Ameriko je imelo svoj epicenter v Nadiških dolinah (87 odstotkov primerov). Delno je zajelo Tersko dolino in nekatera sosednja območja, manjše število izseljencev pa je razpršeno izviralo še od drugod v Furlaniji. Število odhodov iz Nadiških občin je bilo enako desetim odstotkom prebivalstva, naštetega ob popisu leta 1911. Prednjačile so občine Sveti Lenart, Sovodnje in Špeter, z nekoliko manjšim številom so sledile občine Srednje, Grmek in nato še Podbonesec in Dreka. Tudi v primerjavi s številom prebivalstva je pojav najbolj izstopal v občinah Sveti Lenart in zlasti v Sovodnjah, močan pa je bil tudi v občinah Grmek, Srednje in Dreka. V letih pred prvo svetovno vojno so te občine sodile med najbolj izrazita območja izseljevanja v Furlaniji, saj je bilo leta 1909 število čezoceanskih in kontinentalnih izseljencev v Svetem Lenartu enako 18 odstotkom prebivalstva, v občini Grmek več kot 31 odstotkom, povprečje špeterskega okraja, ki je obsegal vse omenjene občine, pa je bilo 12 odstotkov (Picotti 1909). Izseljevanje je bilo najbolj intenzivno v višjih predelih, kjer se je agrarno gospodarstvo soočalo z najtežjimi razmerami.

Tabela 4: Izseljenci po občinah izvora in v razmerju s številom prebivalstva 1911

\begin{tabular}{|c|c|c|c|}
\hline Občina & Število & Odstotek & Odstotkov preb. \\
\hline Dreka & 151 & 7,6 & 10,6 \\
\hline Grmek & 212 & 10,6 & 12,6 \\
\hline Podbonesec & 180 & 9,0 & 4,5 \\
\hline Sveti Lenart & 363 & 18,2 & 13,8 \\
\hline Sovodnje & 315 & 15,8 & 15,5 \\
\hline Srednje & 232 & 11,6 & 11,6 \\
\hline Špeter & 297 & 14,9 & 8,4 \\
\hline Nadiške doline & $\mathbf{1 7 5 0}$ & $\mathbf{8 7 , 6}$ & $\mathbf{1 0 , 1}$ \\
\hline Bardo & 41 & 2,1 & 1,4 \\
\hline Čenta & 39 & 2,0 & 1,4 \\
\hline Praprotno & 63 & 3,2 & 2,8 \\
\hline Tavorjana & 34 & 1,7 & 1,0 \\
\hline Terske doline & $\mathbf{1 7 7}$ & $\mathbf{8 , 9}$ & $\mathbf{1 , 5}$ \\
\hline Drugo & 70 & 3,5 & - \\
\hline
\end{tabular}


Čezoceanski izseljenci so se že v prvem valu usmerili proti različnim ciljem v ZDA. Njihove poti so se z leti tako razvejale, da so držale v kar 21 zveznih držav. Glavnina (81 odstotkov) je bila namenjena v zvezne države Illinois, Pensilvanija, Indiana in Ohio, kjer se je osredotočila na nekatera specifična območja. V zvezni državi Illinois (43 odstotkov) je bil skoraj izključni cilj Čikago, ki je v ZDA veljal za nekakšno beneškoslovensko prestolnico, kjer so priseljenci ustanovili svoje društvo. V Pensilvaniji, kamor je odšlo 18 odstotkov priseljencev, so izstopali premogovniški in industrijski kraji okrog Pittsburgha, predvsem mesteci Indiana in Iselin. V Indiani (14 odstotkov) se je večina priseljevala v Indianapolis, v državi Ohio (7 odstotkov) pa v železarski Cleveland. Med drugimi so omembe vredna mesteca Chisholm in Hibbing v rudarskem okrožju Iron range v Minnesoti, New York, Seattle in Spokane v državi Washington, v Kanadi pa že omenjeni Nanaimo na območju Vancouvra. Glavni priseljenski kraji v ZDA so bili tudi cilji priseljevanja iz Slovenije, predvsem Čikago, rudarski centri okrog Pittsburgha in v Minnesoti ter Cleveland, največje »slovensko« mesto v Ameriki.

Italijanski izseljenci so lahko $v$ Ameriko $z$ italijanskimi ladjami in $v$ spremstvu državnih inšpektorjev, ki so skrbeli za spoštovanje pravnega reda na ladjah, odpotovali iz Genove, Neaplja in drugih domačih pristanišč. Iz severnoevropskih pristanišč so večinoma odhajali izseljenci iz Srednje in Vzhodne Evrope. Med temi so bili tudi beneški izseljenci, ki so v glavnem uporabljali proge iz francoskega Le Havra v Zgornji Normandiji. Tu se je do prve svetovne vojne vkrcalo 77,8 odstotka, skupno pa 64,5 odstotka vseh izseljencev in Benečije, ki so tja skozi švicarski Buchs in Pariz pripotovali z železnico. Za tem je stala agenturna zveza, ki je izseljencem nudila potrebno zaslombo. Po vojni se ta kanal ni več obnovil in tok se je preusmeril proti italijanskim pristaniščem, zlasti Genovi. Od tod je odpotovalo 16,8 odstotka predvojnih izseljencev, po vojni pa 65,7 odstotka. Preostali so pred vojno večinoma potovali skozi Cherbourg v Spodnji Normandiji, Neapelj in angleški Southampton. Tržaške proge za ZDA, ki so jih vzpostavili leta 1904, so začeli uporabljati šele po prvi svetovni vojni, ko se je čezoceanski potniški promet na novo organiziral in so prišla bolj do izraza nacionalna pristanišča.

\section{POKLICNI PROFIL IZSELJENCEV, SOCIALNE MREŽE IN USTALITEV V ZDA}

Med beneškoslovenskim priseljevanjem so bile ZDA že med najbolj industrializiranimi državami. Rast njihovega gospodarstva je bila odvisna od množičnega priliva delovnih rok. Vzporedno z gospodarsko ekspanzijo sta potekali pospešena urbanizacija in modernizacija proizvodnih procesov. 'Novi priseljenci' (new immigrants) so večinoma izvirali iz kmečkega sveta in so prihajali prodajat svojo delovno silo na trg, ki je zaradi tehničnega in organizacijskega razvoja ter delitve dela ob kvalificiranih poklicih vse bolj vključeval tudi množico delovne sile brez posebnih strokovnih znanj. To je veljalo predvsem v določenih sektorjih, kot so energetski, gradbeno-infrastrukturni in prehrambeno-predelovalni, ki se jih je ameriško delavstvo zaradi 
težkih delovnih razmer in nižjih mezd izogibalo. Pri beneškoslovenskih izseljencih je jasno izražena poklicna struktura, značilna za »novo imigracijo« (Tabela 5). Podatki so strnjeni v nekaj širših klasifikacijah in se nanašajo na priseljence, ob prvem vstopu v ZDA starejše od 15 let.

Tabela 5: Poklicni sestav priseljencev in priseljenk

\begin{tabular}{|c|c|c|c|c|}
\hline & \multicolumn{2}{|c|}{ Moški } & \multicolumn{2}{c|}{ Ženske } \\
\hline & Število & Odstotek & Število & Odstotek \\
\hline Poklicno opredeljeni & 146 & 10,5 & & \\
\hline Gradbeni delavci & 84 & 6,0 & & \\
\hline Rudarji & 20 & 1,4 & & \\
\hline Drugi & 42 & 2,6 & & \\
\hline Kmetje in agrarni delavci & 223 & 16,0 & 36 & 16,2 \\
\hline Splošni delavci & 1.028 & 73,6 & & \\
\hline Gospodinje & & & & \\
\hline Šivilje & & & 132 & 59,5 \\
\hline Služkinje & & & 40 & 18,0 \\
\hline Skupno & & & & 100,0 \\
\hline
\end{tabular}

Samo deset odstotkov priseljencev je bilo poklicno opredeljenih, največ $v$ gradbenem sektorju. Zidarstvo je bil tradicionalen in najbolj razširjen poklic v Beneški Sloveniji. V potniških seznamih so zidarje registrirali z izrazom mason, drugič priseljene tudi z bricklayer, kar kaže na specializacijo $v$ ameriškem načinu gradnje $z$ neometano opeko. Zidarji, tesarji in kamnoseki so spadali med kvalificirane delavce in so med beneškoslovenskimi izseljenci veljali za nekakšno delovno elito. Druga specializirana skupina so bili rudarji, drugi priseljenci s poklicem pa so bili mizarji, krojači, nekaj pekov in čevljarjev, kak mehanik in nekaj trgovcev. Preostalih 90 odstotkov moških priseljencev ni imelo poklicnih kvalifikacij in so sodili med najpreprostejši proletariat. Izjavljali so se za 'kmečke posestnike' (farmer, 6,4 odstotka), predvsem pa za 'agrarne in splošne mezdne delavce' (farm laborer, laborer, worker, dailyman). Poročene priseljenke so označene kot gospodinje in le izjemoma s poklicem ali z dejavnostjo. Pogosteje so gospodarske vloge navedene pri neporočenih ženskah, med katerimi so bile poleg kmetic in agrarnih dninark šivilje in predvsem služkinje.

Benečani, ki so se odpravljali v Ameriko, so imeli bogate selitvene izkušnje. Navajeni so bili potovanj in vešči organizacije, povezane z delovno mobilnostjo. Življenje družin in vaških skupnosti v Beneški Sloveniji je bilo usklajeno s ponavljajočim odhajanjem na sezonsko delo. Vključevanje na atlantski delovni trg pa je 
bil v marsičem drugačen proces, ki je terjal na novo zamišljene selitvene načrte, prilagajanje namenom in drugačnim delovnim razmeram kot tudi reorganizacijo dela ter življenja družin. Sezonska migracija se je ponavljala v točno določenih mesecih, sledila je utečenim potem, ki so izseljence vodile $v$ znane kraje. Temeljila je na dogovorih ali vnaprej sklenjenih pogodbah z delodajalci (Picotti 1909), potekala je prosto $v$ skladu z delovno zakonodajo in večinoma brez specifičnih regulativov. Amerika je bila na drugi strani oceana, tja se je odhajalo za dalj časa in brez zanesljivega datuma vrnitve. Pot je bila neprimerno dražja, vstop v državo ni bil številčno omejen, a prišleka niso sprejeli, če ni izkazoval predpisanih pogojev. Na trgu dela so veljala drugačna pravila, predvsem prepoved pogodbenih zavez delavcev $z$ delodajalci pred prihodom v Ameriko, pravilo, ki so ga na zahtevo sindikatov sprejeli že v osemdesetih letih. Priseljenci si zato niso mogli vnaprej priskrbeti dela. Kljub utečeni organizaciji in posebni zakonski zaščiti so se med potovanjem lahko zapletli v vrsto pasti raznih dobičkarjev. Težavnejša je bila tudi vrnitev v primeru brezposelnosti in pomanjkanja sredstev za potovanje. Zaradi vsega tega so pri poteku in usmerjanju priseljevanja igrala pomembno vlogo poznanstva in družbene mreže. Odhodi so bili pogosto dogovorjeni s predhodniki, ki so iz Amerike poročali o delovnih razmerah, pomagali novim prišlekom do zaposlitve in stanovanja ter še kako drugače lajšali njihovo vključevanje v priseljensko okolje, včasih pa jim tudi posodili denar za čezoceansko pot. Usklajevanje je potekalo preko korespondence, ki je bila najpomembnejši vir informacij in s tem dejavnik uravnavanja priseljevanja. Osebni kontakti, ki so jih prišleki navedli ob vstopu v državo, so pred ameriškimi oblastmi veljali tudi kot jamstvo, da bodo pri prvih korakih v ZDA deležni pomoči (Steidl 2007: 87).

Tabela 6: Razmerje priseljencev s kontaktno osebo v Ameriki (starost >15 let)

\begin{tabular}{|c|c|c|c|c|}
\hline \multicolumn{2}{|c|}{ Moški } & \multicolumn{2}{c|}{ Ženske } \\
\hline & Število & Odstotki & Število & Odstotki \\
\hline Bratranec/sestrična & 427 & 26,2 & 16 & 7,0 \\
\hline Brat/sestra & 277 & 17,0 & 43 & 18,9 \\
\hline Svak/svakinja & 151 & 9,3 & 18 & 7,9 \\
\hline Stric/teta & 55 & 3,4 & 10 & 4,4 \\
\hline Oče & 26 & 1,6 & 13 & 5,7 \\
\hline Mož & & & 95 & 41,7 \\
\hline Drugi sorodnik & 30 & 1,8 & 4 & 1,8 \\
\hline Prijatelj/prijateljica & 621 & 38,1 & 8 & 3,5 \\
\hline Zaročenec & & & 21 & 9,2 \\
\hline Nihče & 45 & 2,8 & & 100,0 \\
\hline Skupno & 1.632 & 100,0 & 228 & \\
\hline
\end{tabular}

Rubrika, ki je v potniških seznamih spraševala, $\mathrm{h}$ komu je priseljenec namenjen in o njegovem razmerju z navedeno osebo, odpira vpogled v mrežo družbenih vezi, ki je nudila oporo verižnemu procesu priseljevanja. Skoraj vsi priseljenci iz Benečije 
so razpolagali z zaslombo v Ameriki (Tabela 6). Mreža kontaktov se ni omejevala na družinsko in sorodstveno sfero in se je razlikovala glede na spol. 38 odstotkov priseljencev se je oprlo na prijatelje, preostali pa na sorodnike, zlasti bratrance in brate. Pri priseljenkah je bil kontakt skoraj izključno znotraj sorodstva. Zaradi maloštevilčnosti žensk je bila manjša tudi njihova posredniška vloga do trga dela.

Struktura oporne mreže je, kot kažejo primerjave med priseljenskimi skupinami iz raznih evropskih območij, izraz tipologije oziroma razvojne stopnje procesa priseljevanja. Skupnosti z dolgo tradicijo priseljevanja, večjim deležem celih družin in bolj uravnoteženo sorodstveno strukturo izkazujejo v oporni mreži v obravnavanem obdobju več članov ožjega in širšega sorodstva. Pri skupinah, ki so se začele priseljevati pozneje in še niso imele večgeneracijskih korenin v ZDA, so prevladovale vezi izvorne družine in bližjega sorodstva. Struktura vezi se je razlikovala tudi glede na narodnost in veroizpoved ter s tem povezanimi kulturnimi specifikami, družinsko tipologijo ter razmerji med sorodstvom (Steidl 2007: 89). Beneškoslovenski priseljenci odstopajo od nakazane sheme zaradi primarne vloge bratrancev, ki so pri drugih sočasnih priseljenskih skupinah šele na tretjem mestu po svakih in bratih (prav tam: 90), in predvsem prijateljev. To lahko pripišemo dejstvu, da je bilo priseljevanje v začetni fazi, in mehanizmom dostopa do delovnega trga. Pot do zaposlovanja ni vodila nujno prek naveze s sorodniki, zlasti če so priseljenci prihajali z namenom, da se po določenem času vrnejo domov. $V$ teh primerih so bile pomembnejše vezi v krajih zaposlovanja. Pri priseljenkah se kažeta dve težnji. Poročene in zaročene so sledile svojim soprogom in zaročencem, druge so se naslanjale na člane izvorne družine (brate, sestre, očete), svake in veliko manj kot moški na bratrance. $S$ tem se spet kaže, kako je bilo žensko priseljevanje povezano bolj z združevanjem družin, s stabilizacijo priseljencev v Ameriki in z navezanostjo ženske mobilnosti na zaščitene družinske ali sorodstvene okvire.

Tabela 7: Razmerje priseljencev s kontaktno osebo po obdobjih (v odstotkih, starost >15 let)

\begin{tabular}{|c|c|c|c|c|c|c|}
\hline \multicolumn{3}{|c|}{ Moški } & \multicolumn{3}{c|}{ Ženske } \\
\hline & -1910 & $\mathbf{1 9 1 1 - 1 5}$ & $\mathbf{1 9 1 9 -}$ & -1910 & $\mathbf{1 9 1 1 - 1 5}$ & $1919-$ \\
\hline Bratranec/sestrična & & & & & & \\
\hline Brat/sestra & 27,4 & 23,2 & 24,3 & 10,2 & 10,6 & 4,5 \\
\hline Svak/svakinja & 14,9 & 17,3 & 31,6 & 20,4 & 25,5 & 15,9 \\
\hline Stric/teta & 3,6 & 9,8 & 12,5 & 10,2 & 12,8 & 5,3 \\
\hline Oče & 0,9 & 2,5 & 7,2 & 6,1 & 2,1 & 4,5 \\
\hline Mož & & & 6,6 & 2,0 & 4,3 & 7,6 \\
\hline Drug sorodnik & 1,4 & 1,1 & 6,6 & & 2,1 & 2,3 \\
\hline Prijatelj & 40,6 & 41,6 & 11,2 & 12,2 & & 1,5 \\
\hline Zaročenec & & & & 6,1 & 6,4 & 11,4 \\
\hline Nihče & 3,1 & 2,8 & & & & \\
\hline Skupno & 100,0 & 100,0 & 100,0 & 100,0 & 100,0 & 100,0 \\
\hline
\end{tabular}


Izseljevanje iz Beneške Slovenije v Ameriko je povezovalo izseljence s celotnega območja v vzajemen sistem družinskih in širših relacij. Te so bile lahko tesne ali ohlapne, vsekakor pa funkcionalne pri vključevanju v delovno in življenjsko okolje. Družbeni network odraža v časovni perspektivi še dodatne vidike povezovanja in samega migracijskega procesa (Tabela 7). Dokler je bil proces v polnem teku, so v oporni družbeni mreži igrali pomembno vlogo prijatelji in vsi v neposrednem stiku z možnostmi zaposlitve. Ko se je po vojni narava izseljevanja spremenila, je v poštev prišlo večinoma samo še pridruževanje sorodnikom. Medtem se je struktura družin in sorodstva $v$ Ameriki razširila in okrepila. Oporna vloga bratrancev je že pred vojno upadla, medtem ko je naraščala vloga članov nuklearne družine (bratov, očetov) in najbližjih sorodstvenih vej. Pri ženskah sta razlika med predvojno in povojno fazo ter učinek trajnega naseljevanja v ZDA še bolj poudarjena: po vojni se je med navedenimi kontakti znatno povečal delež soprogov, zaročencev in očetov, upadel pa delež bratrancev, bratov, stricev in svakov. Skratka, povečal se je proces združevanja družin.

Še nekaj vprašanj. Prvič, koliko izseljencev iz Benečije se je iz Amerike vrnilo v rodne doline in koliko jih je tam ostalo? O tem lahko indikativno sklepamo s pomočjo registrov prebivalstva občine Sovodnje, v katerih so zabeleženi stalno odsotni občani. Med temi jih je na začetku tridesetih let v Severni Ameriki živelo 156 (Kalc 2000: 199). To število odgovarja 60 odstotkom izseljencev iz te občine, evidentiranih na ladijskih seznamih potnikov. Povratništvo naj bi se torej v grobem gibalo okrog 40 odstotkov, kar se je skladalo s splošnimi težnjami vračanja v letih pred prvo svetovno vojno. Sklepati smemo, da je podobno veljalo tudi za druge občine. Drugo vprašanje se nanaša na soprisotnost tradicionalne sezonske oziroma kontinentalne migracije in čezoceanskega izseljevanja. Študije kažejo, da so prve zmanjševale verjetnost razvoja drugih in da so se druge pojavljale bolj na območjih, kjer niso bile utečene migracije krajšega trajanja (Steidl idr. 2007: 86). To je nedvomno veljalo za Furlanijo, ne pa za Beneško Slovenijo. Kakšno je bilo potemtakem v Benečiji razmerje med tradicionalnim sezonskim in čezoceanskim izseljevanjem? V kolikšni meri sta se obliki izključevali oziroma dopolnjevali v prizadevanju za zagotavljanje obstoja v izvornem kraju? Katere so bile diskriminante te kombinacije oziroma diferenciacije? To vprašanje se tiče tako vaških skupnosti, ki so se včasih občutno razlikovale tako po stopnji in vrsti selitev kot vrsti družin. Nekaj elementov k tej razpravi ponujajo podatki o položaju izseljencev iz občine Sovodnje v njihovih izvornih družinah. Med stalnimi izseljenci so s 40 odstotki prednjačili bratje družinskega poglavarja, ki so bili skoraj izključno samski. 26 odstotkov je bilo sinov in osem odstotkov hčera, ki so se delno še kot otroci izselili s starši, delno pa že kot odrasli samski ali poročeni; 24 odstotkov je bilo družinskih poglavarjev, osem odstotkov soprog, medtem ko je bilo sester le štiri odstotke, svakov pa tri (Kalc 2000: 199). Izseljenska erozija je torej v obravnavanem obdobju prizadela predvsem tiste člene skupnosti in družin, ki so bili v tradicionalnem, na kmetijski podlagi slonečem družbenoekonomskem kontekstu v podrejenem položaju. Imeli so slabša izhodišča za dosego gospodarske samostojnosti in družinske reprodukcije. To pomeni tudi več motivacij za dolgoročnejšo 
zapustitev domačega kraja in iskanje priložnosti za realizacijo življenjskih načrtov v drugih okoljih. Ker se čezoceanske vezi niso pretrgale in so pogosto vsaj še določen čas prispevale ekonomske vire izvornim krajem, to ni nujno pomenilo definitivnega odklopa iz sistema. Vključitev $v$ atlantski tok delovnih migracij pa je bila nedvomno prelomno dejanje $v$ srečevanju Beneške Slovenije z izzivi modernizacije.

\section{SKLEP}

Glede na uporabljeni dokumentarni vir se je izseljevanje iz Beneške Slovenije v ZDA pokazalo $v$ svojih dinamičnih in strukturnih značilnostih. Rekonstrukcija diahrone podatkovne vrste je omogočila opazovanje pojava vzdolž njegovega celotnega poteka v povezavi s širšim kontekstom migracijskega dogajanja in družbenoekonomskega položaja Beneške Slovenije v času pred prvo svetovno vojno in takoj po njej. Do izraza so prišli elementi, ki opozarjajo na kompleksnost migracijskega procesa, in statistično težje zaznavni dejavniki, kot so družbene mreže, ki so delovale kot opora priseljevanju in ohranjanju čezoceanskih vezi. Pokazala pa so se predvsem vprašanja o relacijah med raznimi migracijskimi tipologijami in izbirami. Preklop iz tradicionalnega sezonskega in kontinentalnega migracijskega sistema na atlantski migracijski sistem je spremenil odnos do družbenoekonomske tradicije. Ta je temeljila na izpiljenem usklajevanju krajevnih ter zunanjih virov dohodka, ki so jih zagotavljale delovne migracije. ZDA so bile po eni strani alternativna varianta za premagovanje neravnovesja med potrebami vse številčnejšega prebivalstva in njegovimi krajevnimi gospodarskimi viri. Za tiste, ki so se ustalili na ameriških tleh, pa je čezoceansko izseljevanje pomenilo rez s konservativno logiko in sprijaznjenim vztrajanjem ohranjanja gospodarske in socialne tradicije. To je bila množična reakcija na vse večjo marginalizacijo hribovitih območij in znanilka dramatičnega depopulacijskega procesa, ki je zajel Beneško Slovenijo po drugi svetovni vojni. 


\section{VIRI IN LITERATURA}

Blanchini, Eugenio (1898). La proprietà agraria nel Friuli Italiano ed i bisogni economici e sociali. Videm.

Cosattini, Giovanni (1903). L'emigrazione temporanea del Friuli. Rim: Bertero e C.

Donato, Katharine M., Gabaccia, Donna (2015). Gender and International Migration. New York: Russell Sage Foundation.

Drnovšek, Marjan (1999). Okrajna poročila o izseljevanju iz Kranjske v letih 1892-1913. Gestrinov zbornik (ur. Darja Mihelič). Ljubljana: ZRC SAZU, 413-432.

Glazier, Ira A. (1984). Ships and Passengers in Emigration from Italy to the U.S. 1880-1990. Emigration from Northern, Central and Southern Europe: Theoretical and Methodological Principles of Research. International Symposium, Krakow, Nov. 9-11 1981. Krakow: Nakładem Uniwersytetu Jagiellońskiego, 245-275.

Gortani, Michele, Pittoni, Giacomo (1938). Lo spopolamento montano nella montagna friulana. Rim: INEA.

Kalc, Aleksej (1996). Ladijske potniške evidence kot vir za zgodovino izseljenstva, s posebnim ozirom na izseljenske sezname tržaškega pristanišča. Dve domovini / Two Homelands 7, 51-69.

Kalc, Aleksej (2000). Prispevki za zgodovino izseljevanja iz Beneške Slovenije: Primer občine Sovodnje/Savogna. Dve domovini / Two Homelands 11/12, 175-200.

Keeling, Drew (2012). The Business of Transatlantic Migration Between Europe and the United States 1900-1914. Zürich: Chronos.

Meneghel, Giovanna, Battigelli, Franca (1977). Contributi geografici allo studio dei fenomeni migratori in Italia. Pisa: Pacini.

Musoni, Francesco (1902). Sull'emigrazione, specialmente temporanea, dal Veneto e più particolarmente dal Friuli. Atti del IV Congresso Geografico Italiano. Milano.

Musoni, Francesco (1912). Gli abitanti, il loro numero e la loro distribuzione. Guida delle Prealpi Giulie (ur. Olinto Marinelli). Videm: S.A.F.

Pagani, Maria Bianca (1968). L'emigrazione friulana dalla metà del secolo XIX al 1940. Videm: Arti Grafiche Friulane.

Picotti, Guido (1909). L'intensità del fenomeno migratorio nel circondario di Udine. La Patria del Friuli, Videm, 28. 10.

Puskas, Juliana (1991). Hungarian Overseas Migration: A Microanalysis. A Century of European Migrations 1830-1930 (ur. Rudolph J. Vecoli, Suzan M. Sinke). Čikago: University of Illinois Press, 221-239.

Ridolfi, Luigi (1921). I Friulani nell'America del Nord. Videm: Arti Grafiche.

Ruttar, Riccardo, Clavora, Ferruccio (1990). La comunità senza nome. Premariacco: ZSIFJK.

Salvetti, Patrizia (1987). II movimento migratorio italiano durante la prima guerra mondiale. Studi emigrazione 87, 282-295.

Sori, Ettore (1979). L'emigrazione italiana dall'Unità alla seconda guerra mondiale. Bologna: II Mulino. 
Specogna, Efrem (2009). Raminghi sulla costa del Pacifico: In cerca di fortuna / Gledat srečo! (Tipkopis). Nanaimo.

Steidl, Annemarie (2007). The »Relatives and Friends Effect«: Migration Networks of Transatlantic Migrants From the Late Habsburg Monarchy. Maritime Transport and Migration: The Connexions between Maritime and Migration Networks (ur. Torsten Feys). St. John's Neufoundland: IMEHA, 75-96.

Steidl, Annemarie, Stockhammer, Engelbert, Zeitlhofer, Hermann (2007). Relations among Internal, Continental and Transatlantic Emigration in Late Imperial Austria. Social Science History 1, 62-92.

Steidl, Annemarie (2009). Transatlantic Migration from the Late Austrian Empire and in Relation to Rural-Urban Stage Migration. European Mobility: Internal, International, and Transatlantic Moves in the 19th and Early 20th centuries (ur. Annemarie Steidl, Josef Ehmer, Stan Nadel, Hermann Zeitlhofer). Göttingen: V\&Runipress, 207-227.

Steidl, Annemarie (2014). On Many Roads: Internal, European, and Transatlantic Migration in the Habsburg Monarchy, 1850-1914. Habilitationsschrift, eingereicht an der Historisch-Kulturwissenschaftlichen Fakultät der Universität Wien. 


\section{SUMMARY}

\section{EMIGRATION FROM VENETIAN SLOVENIA TO NORTH AMERICA AT THE BEGINNING OF THE $20^{\text {TH }}$ CENTURY ON THE BASIS OF PASSENGER LISTS Aleksej KALC}

The paper examines the little-known phenomenon of emigration from Venetian Slovenia to the USA from the beginning of the 20th century to the 1930s. The analysis is based on passenger lists compiled by the US immigration authorities. The dynamic and structural characteristics of the overseas migration are presented in comparison with the seasonal labour migrations prevailing in Friuli and in Venetian Slovenia at the time. The overseas migrants were predominantly men heading to mining and industrial centres. Apart from ten percent of skilled workers, mainly masons, the emigrants were unskilled labourers. They commuted from the European seasonal labour market to the longer-lasting and often repeated labour periods in the USA. Most of them, however, settled in America permanently, which coincided with the immigration of women (16\%), especially wives and other members of the nuclear family, whose arrivals were concentrated in the years after WWI. The emigration to the USA was a turning point in Venetian Slovenia's migration history, as it marked a deviation from the seasonal tradition and the conservative socio-economic strategies of the rural communities. This was the first significant permanent emigration from the area and resulted in a loss of residents in the post-WWI period. 